\title{
MULHERES PERFEITAS: condição social e instrução feminina em São Luís (1900-1930)
}

Tatiane da Silva Sales

graduada pela UEMA

\begin{abstract}
Resumo: Este estudo pretende discutir o papel desempenhado pela instrução na formação da mulher nos moldes tradicionais, em meio a uma sociedade que se pretendia moderna, sob os auspícios da nova ordem republicana. As funções sociais que recaíam sobre as mulheres primavam ainda pelo âmbito privado, tendo no tripé filha, esposa e mãe, como base na formação e orientação nas atribuições femininas. Apresentam-se as mudanças urbanas, sociais e educacionais ocorridas em São Luís, e suas implicações na contribuição dos modelos femininos segundo os ideais burgueses de família e sociedade.
\end{abstract}

Palavras-Chave: Educação Feminina. Esposa. Mãe. São Luís.

\begin{abstract}
This study it intends to argue the role played for the education in the formation of the womam in the traditional molds, in way to a society thatif intended modern, under of the new republican order. The social functions that fell again on the women still primavam for the domestic scope, having the tripod son, wife and mother as base in the formation and prompt in the feminine attributions. One presents urban, social and aducational the changes accured in São Luis, and its implications in the contribution of according to bourgeois ideal the feminine models of family and society.
\end{abstract}

Keyworks: Feminine education. Wife. Mother. São Luís.

O século XX e seu discurso do moderno despontam como um período de importantes modificações e ampliações para a instrução feminina no Brasil, porém embora respaldados pelo ideal republicano, os objetivos da estrutura educacional permanecem praticamente inalterados, ou seja, tinham a proposta de preparar a mulher para o exercício da sua missão maior, a de ser mãe, esposa e dona de casa.

Dessa forma, o presente trabalho visa analisar a educação feminina sob a ordem republicana, tendo como palco a cidade de São Luís nos primeiros anos do século XX e apresentando as ampliações que a escolaridade exercia sobre o 'melhor preparo' do desempenho das 'funções' entendidas como exclusivamente femininas. 
A cidade de São Luís, no início da República, estava inserida no projeto republicano de modernização, que embalava todo o país. Muitos dos casarões existentes estavam sendo habitados efetivamente somente neste momento, pois fazendeiros do interior do estado deixaram o já não mais lucrativo negócio do campo pela vida urbana que despontava com novas oportunidades de investimento, e em contrapartida outra parte de casarões estavam sendo abandonados e cedendo lugar a cortiços.

O ideal republicano proporcionou discussões acerca de modernidade, e tais debates permitiram abertura de espaço para inovações materiais e sociais. Tamanha relação com o novo proporcionava resultados diversos em cada um dos indivíduos da zona urbana. A fotografia levava as recordações de um passado e a valorização dos momentos pessoais, além de ser um novo testemunho das modificações de São Luís como o álbum de 1905 onde são registradas as imagens de ruas, armazéns e praças como a João Lisboa - e a grande circulação de pessoas. Os novos meios de comunicação diminuíam as distâncias e as redes de estradas de ferro, a REFESA em São Luís, dinamizavam a comercialização de produtos e o transporte de pessoas.

Desenvolveu-se também toda uma alteração e preocupação com a paisagística da cidade, afinal, o padrão influenciador para as capitais do Brasil era a Europa. Em São Luís foi estabelecido o Código de Posturas de $1866^{1}$ que apresenta algumas normas e regras para a construção de moradias na cidade, chegando até mesmo a proibir a construção de casas com teto de palha, pois estas entrariam em contraste com a beleza dos casarões, e a regulamentar a postura e ação das pessoas nos espaços públicos.

Entender a cidade como ponto de intercessão entre a idealidade e a concretude; como lócus privilegiado de relações sociais, as mudanças na economia que constituía um dos seus fundamentos, não poderiam deixar de se exprimir na ocupação do espaço. (CORREIA, 2006, p.29).

A cidade apresentava-se então como um local de diferenciação social, e em seus espaços tais diferenças faziam-se latentes, para tanto, primar pela qualidade do aspecto físico da cidade era realizar controle sobre a pobreza, e permitir que o novo cidadão urbano e republicano estivesse inserido inteiramente na proposta de soerguer uma cidade sob os auspícios da nova ordem republicana.

\footnotetext{
${ }^{1}$ Note que ainda desde a segunda metade do século XIX a preocupação de regulamentar os hábitos da cidade já se tornam uma realidade.
} 
Com o objetivo de implementar nos ludovicenses a noção de bem estar e bem viver, foi grande a difusão de peças teatrais e do cinema itinerante na cidade. As apresentações no Teatro São Luís (atual Teatro Arthur Azevedo) contribuíram fortemente para a propagação do modo de vida estabelecido na capital federal, e até mesmo para a difusão da cultura de países europeus (principalmente França). Os vários atores e atrizes das peças e dos filmes, os cantores e cantoras, traziam consigo os símbolos da modernidade, a partir das experiências de outras localidades, mais do que idealizar os romances apresentados nesses filmes, a sociedade idealizava todo seu modo de vida, seus hábitos e seu cotidiano que era entendido como símbolo do "moderno".

Os jornais de São Luís eram responsáveis por massificar as informações da moda européia para a elite da cidade, e apresentavam figurinos da tendência que deveria ser seguida pela elite ludovicense, contribuindo para manter um enorme grau de diferenciação da maioria dos moradores da cidade. O periódico "O Jornal” foi um dos que contribuía para a elite maranhense, deixando-a sempre em dia com a moda européia, fato este comprovado por sua coluna intitulada "A Moda".

O maior contato com médicos e questões sanitárias contribuiu fortemente para propagação do início do século XX como marco de um novo tempo. A ordem médica estabeleceu-se como um padrão, e recaíam muitas exigências sobre as famílias de elite, tanto que a grande influência da ordenação médica se estabeleceu não apenas na concepção de limpeza e saúde, mas também envolveu relações conjugais, escolha do cônjuge, cuidado e educação dos filhos, etc., o que de certa forma condicionou ao médico representativo poder de influência nas relações familiares, isto se deu muito pela noção de valorização da ciência, e em especial a medicina.

\footnotetext{
A seleção do parceiro conjugal tornou-se uma questão capital para higiene. A saúde do filho não dependia apenas do trato que lhe fosse dado após o nascimento. Ela estava condicionada à saúde dos pais. [...] No casamento idealmente concebido pela higiene o casal olhava o futuro e não o passado. Seu compromisso era com os filhos e não com os pais. A escolha do cônjuge estava manietada a esta proposição. O cuidado com a prole converteu-se, por esta via, no grande paradigma da união conjugal. (COSTA, 1979, p.219).
}

A higienização do espaço urbano adentrava nos lares ludovicenses, regulando o cotidiano dessa população, suas escolhas de lazer, prazer e seus parceiros conjugais. A 
partir de então, o discurso religioso ganhou mais uma competição, o discurso médico, e isto fez com que muitas famílias procurassem os médicos para solução de suas moléstias.

É diante desse novo contexto da história do Brasil, de uma nova concepção de casamento, cuidado com os filhos, relacionamento conjugal e instrução, que nasce uma considerada 'nova mulher', e a via educacional cooperou para este acontecimento.

A educação em São Luís, de uma forma geral, teve uma significativa mudança na virada do século. Muitas foram as melhorias na instrução registradas em falas e mensagens de governantes e autoridades, notadamente estes documentos se referem à educação pública e fazem parte da divulgação dos respectivos governos, fato que torna o discurso mais propício a revelar e maquiar a atuação dos governos diante do público maranhense.

A mulher adentrou o século XX com uma educação de mais qualidade, maiores vagas nas escolas, ampliação das disciplinas oferecidas e até o direito de estudar na mesma sala que os homens. Esses procedimentos educacionais contribuíram para o processo de "conquista" do espaço público pela mulher, o que resultou na maior atuação desta "nova mulher' para além dos espaços do lar e da igreja, únicos ambientes em que a ação feminina se fazia mais notória.

Como em diversos setores, a República foi palco das transformações no campo educacional, e algumas reformas alteraram a estrutura do ensino, dividindo-o em primário, secundário e profissional, incluiu-se também a discussão de proibição de agressões físicas na escola, fato que concedeu maior mobilidade ao ensino no Brasil. Em São Luís, o governo de Benedito Leite (1906-1910) abriu algumas portas importantes para o desenvolvimento da educação no estado, foi criada a Escola Modelo, realizadas reformulações na escola Normal, melhorias na Biblioteca Pública e na Imprensa Oficial.

Porém, algumas reformulações no ensino não acompanharam o ritmo das mudanças citadas acima, a educação ainda era muito mecânica, e privilegiava um ensino baseado em matérias meramente decorativas e vazias de significações, não atribuindo nenhum significado aos alunos.

Bastaria interrogarem-me para que os trechos da Gramática saíssem no próprio compêndio de Pedro de Souza Guimarães.Só receava um perigo: inverterem a ordem das perguntas ou fazerem-nas por forma diversa da do compêndio. Isso, todavia se me afigurava uma traição, de que, aliás, eu era vitima múltiplas vezes. O professor apenas ordenava que decorássemos, 
poupando-se ao trabalho extenuante de destrinçar-nos o texto ou de elucidá-los com exemplos. Tanto quanto podíamos compreender, a nossa educação resumia-se em transvasar para as nossas cabeças o que os livros continham e repeti-lo depois materialmente na aula, ou nos exames de fim de ano, perante uma assembléia de pais e parentes, embevecidos do nosso saber. Não havia interesse em exercitar-nos a inteligência, em adestrá-la na ginástica do raciocínio, em povoá-la de noções proveitosas e úteis a vida (REVISTA DO NORTE, 01/09/1901).

Pode-se perceber o grau de superficialidade que a educação possuía, pautada apenas no decorar textos e levar castigos caso não os decorasse, pois, ainda segundo o depoimento acima diariamente, depois da lição... e dos bolos, ouvia-se esta frase inalterável: 'decore daqui até ali'. E principalmente a instrução pública, pois era nesta esfera que homens e mulheres pobres estavam inseridos, e além do pouco investimento em mais escolas, o método de ensino e os conteúdos não favoreciam um conhecimento que incentivasse a reflexão, o censo crítico ou que objetivassem efetivamente em noções proveitosas e úteis a vida.

Inseriu-se nesta nova proposta educacional espaço maior para as mulheres, uma vez que no século XIX, o ensino implantado na visão positivista, estabeleceu semelhanças e diferenças entre os sexos, propagando o modelo de submissão da mulher ao masculino. No século XX, autoridades, jornais e a sociedade civil de uma forma mais geral defendiam importantes ampliações na educação feminina, no entanto a mulher submetida a esse processo educacional deveria ter consciência do papel fundamental que desempenharia ao estabelecer a figura da mulher ideal, neste momento, a educação ganhou conotação importante na substituição simbólica do dote.

O dote era um antigo costume das famílias patriarcais e tinha um importante papel na formação das famílias quando ainda se carregava a concepção de que tais núcleos eram unidades de produção. Os pais costumavam dotar suas filhas com bens materiais que pudessem contribuir para a formação do patrimônio e sobrevivência do novo casal desde o século XIX, o dote entra em declínio e para conseguir bons casamentos novos atributos foram estabelecidos, dentre eles, o de uma educação mais primorosa.

Paralelamente ao crescimento do amor como incentivo para o casamento e a diminuição do controle dos genitores sobre os casamentos de seus filhos, houve também transformações da mentalité no que diz respeito ao papel adequado do marido no casamento. (NAZZARI, 2001, p.220).

Apesar de algumas permanências da submissão feminina, em novos moldes, especialmente com o discurso científico positivista, a educação teve um importante papel 
no processo da conquista feminina do espaço público, mesmo sendo utilizada para reforçar as tradicionais diferenças entre homens e mulheres e seus papéis sociais. Os estudos relacionando gênero e educação no Brasil tem demonstrado as diferenças nos conteúdos, estratégias de ensino e nos objetivos que envolviam a educação de meninos e meninas.

Dessa forma, eram lançadas sobre as mulheres algumas exigências para que 'soubessem' seu papel na sociedade e o desempenhassem da forma mais honrosa possível. Assim, a mulher deveria se estabelecer e se destacar no âmbito privado, realizando-se neste espaço, com a contribuição social de organizar e zelar pelo bem-estar da família, devendo munir-se de conhecimentos acerca dos afazeres domésticos (prendas), criação dos filhos, higiene e "gerenciamento" do lar, dentre outros.

A educação feminina era vista com muita cautela e algumas vezes divulgava-se que a mulher adquiriria um aspecto 'masculinizante' por meio do estudo excessivo e perderia a sua 'essência'. A mulher, por intermédio da instrução, poderia ocupar cargos dantes preenchidos apenas por homens, a própria discussão do direito ao voto feminino (que já era possível perceber desde o início do século XX) mostrava o leque que a instrução poderia abrir às mulheres, o que era visto como perigoso por parte dos homens, pois sentiam-se, de certa forma, ameaçados, o próprio lar era visto como ameaçado pela possível saída de mulher.

\footnotetext{
Alguém dirá, que desse dia em diante se esfalecerá o lar que até então era o paraíso das flores; pois a mulher poderá discernir dos ideais do marido, e sairá pelas ruas pedindo votos para o seu partido e contra o partido de seu esposo. Assim o resultado será discussões diárias, e má viver entre os dois, porque não se entenderão. Não duvido que isso aconteça (REVISTA MARANHENSE, nov. de 1916).
}

No entanto, ainda que, de alguma maneira, a instrução pudesse representar abertura de novos espaços à mulher, no geral corroborava para a permanência da separação dos papéis no matrimônio e na sociedade. O discurso normativo dos papéis femininos, antes defendido pela Igreja, ganhava cada vez mais o reforço da ciência, e esta contribuiu para a incorporação dos valores masculinos enquanto verdade incontestável, numa clara demonstração daquilo que o filósofo Pierre Bourdieu (2005) chama de "violência simbólica", "violência suave", "invisível e insensível" a suas próprias vítimas, em que a 
lógica da dominação concentra-se no discurso dentro da unidade doméstica, sendo entendido como normal e aceitável.

Não se podem enquadrar todas as mulheres no conjunto de pensamento e reação únicos para os discursos e ações do dia-a-dia, porém ainda era comum perceber como as mulheres de elite de São Luís priorizavam o lar e a sua missão pautada no tripa de filha, esposa e mãe. O jornal maranhense “A Reação" (1913) realizou entrevista com uma ludovicense de classe média, Nirvana Bittencourt Chã, e as questões referiam-se ao lar, família, livros e os assuntos que seriam capazes de ilustrar o papel feminino:

Jornal A Reação: -Qual sua opinião sobre o lar?

Nirvana Bittencourt: - O lar... é o céu da vida terrena, berço dos filhos e túmulo dos velhos, onde aqueles aprendem a ser fiéis, disciplinados, obedientes e honrados, se a família é constituída segundo os princípios da moral católica.

Jornal A Reação: - Que julga ser a felicidade da mulher casada?

Nirvana Bittencourt: - Casar-se é, dizem, comprar um bilhete de loteria, pode, no entanto a mulher encontrar, sempre a felicidade no casamento, desde que se conforme com a boa ou má direção dada pelo marido à vida comum de casal.

Jornal A Reação: _ Que pensa dos livros modernos no ponto de vista da educação intelectual da mulher?

Nirvana Bittencourt: Livros, há, que a mulher é melhor desconhecer e dessa espécie existem muitos entre os modernos.

Nota-se a incorporação de uma visão sobre o feminino sem aparente questionamento, tendo a religião um papel ainda importante para que os valores fossem absorvidos pela família, e para a estruturação e equilíbrio. $\mathrm{O}$ casamento ainda assumia posição de destaque na posição feminina e sua felicidade estaria subjugada ao conformismo das decisões do marido, sobre os livros, único indício da entrevista que leva à questão da educação, a entrevistada prefere desconhecer os que são apresentados como modernos.

No século XIX, cristalizou-se a imagem da mulher que trazia para si toda responsabilidade com as atividades do seu "reino", como por exemplo, o cuidado com filhos, com a alimentação, a higiene, a implantação de valores religiosos no seio do lar; a unidade do lar também estaria sobre sua responsabilidade, uma vez que era exigido desta mulher sabedoria para atrair seu marido ao aconchego da casa e dos filhos, sendo por tanto uma esposa bem disposta, amável e sobretudo silenciosa. Essas imagens e ideais não encerraram-se com o século XIX, e, na verdade foram importantes fomentadoras da formação do pensamento e das perspectivas do século XX. 
A educação voltada para as mulheres funcionou ainda como reforçadora desses ideais, sendo a articulação que contribuiu para que a mulher soubesse seu papel na estruturação da família. Porém, no século XX, esta instrução teve seus campos de estudo alargados, tendo como exemplo a inclusão das mesmas disciplinas que os meninos estudavam ao lado da manutenção das disciplinas femininas como as "Ciências Domésticas", "Prendas Domesticas", “Corte e Costura” dentre outras, estava a inclusão das disciplinas que os meninos estudavam, como pode se observar pelo currículo da Escola Normal de São Luís, criada em 1890, com as seguintes disciplinas:

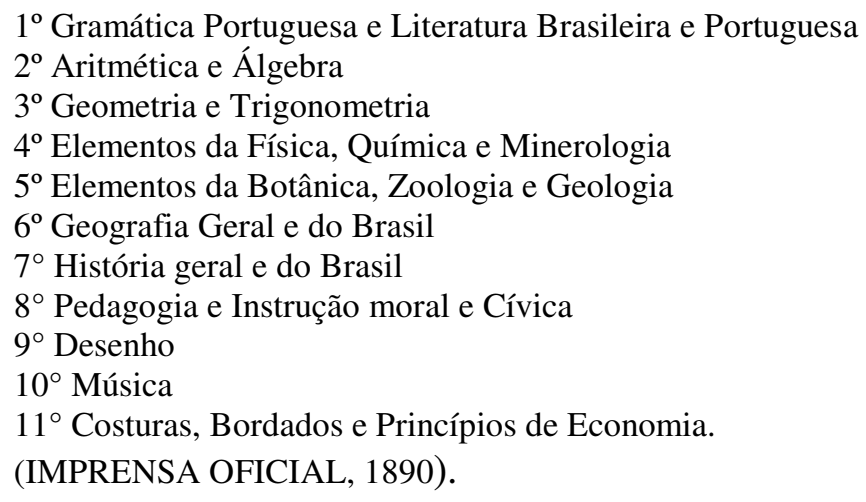

No caso desta última disciplina, de prendas domésticas, era exclusivo para as mulheres, do primário ao secundário. A mulher do novo século encontrava-se envolvida por uma esfera que, diante das diversas mudanças trazidas pela ordem política e pela aceleração do processo de urbanização, padronizava o perfil da mulher num modelo de perfeição para aquela sociedade, sendo responsável pelo equilíbrio da família e da nação.

O dever ser das mulheres brasileiras nas três primeiras décadas do século foi, assim, traçado por um precioso e vigoroso discurso ideológico, que reunia conservadores e diferentes matizes de reformistas e que acabou por desumanizá-las como sujeitos históricos, ao mesmo tempo que cristalizava determinados tipos de comportamento convertendo-os em rígidos papéis sociais. (MALUFF; MOTT, 2006, p. 373 )

Em uma época marcada por novos espaços para a mulher, especialmente as de segmentos médios e altos da sociedade, era necessária a formulação e difusão de imagens da mulher ideal, encaixando-as em atividades que a reportassem para o seu "reino". Foi a partir de então que o século XX reforçou o tripé filha, esposa e mãe. "Assim, se ao marido 
cabia prover a manutenção da família, à mulher restava a identidade social como esposa e mãe. A ele, a identidade pública; a ela, a doméstica” (MALUF; MOTT, 2006, p.379).

Referindo-se ao tipo de comportamento feminino que deveria ser desenvolvido, a Revista Elegante constantemente traçava um perfil de mulher a ser seguido. Com a concepção de candura e inocência, fruto da mentalidade cristã, medieval e ocidental, as mulheres eram enquadradas em dois modelos bem definidos: o de Eva, a pecadora, e o de Maria, a redentora. A revista supracitada traz um exemplo daquilo que a sociedade maranhense esperava de uma mulher:

A mulher na família. A infância da mulher é a mais santa e a mais pura fase de sua existência: é quando ela é virgem. [...] Finalmente ela é a mulher, isto é, deixa de ser a virgem para chamarse 'esposa e mãe', duplo qualitativo que lhe confere o mais elevado grau no importante ministério que lhe destinou na terra o Criador. (REVISTA ELEGANTE, de 30 de jun. de 1893, n. ${ }^{\circ} 16$, ano II) Grifo Nosso

Esses três qualificativos foram constantemente utilizados para dar significado ao modelo feminino esperado pelos homens. Quando solteira, sua grande virtude era ser virgem e pura, e a partir do momento em que se casasse, sua imagem era compreendida pela figura de esposa e mãe, entendida sempre como a concretização de sua missão divina.

Desde o decorrer do século XIX em que a situação feminina vinha sofrendo alterações, as quais foram significativas para as formulações do século XX. Da abertura do espaço doméstico para a realização de bailes e saraus, oportunizando um contato maior das mulheres com a vida social, até o passeio pelas ruas e avenidas dos centros urbanos, acompanhadas ou sozinhas, para o espanto da sociedade no início do século XX, os avanços em relação à emancipação feminina foram acompanhados com preocupação e tentativas de disciplinamento.

A mulher de elite passou a marcar presença em cafés, bailes, teatros e certos acontecimentos da vida social. Se agora era mais livre [...], não só o marido ou o pai vigiavam seus passos, sua conduta era também submetida aos olhos atentos da sociedade. (D’INCAO, 2006, p.228)

A própria diferenciação cada vez maior de público e privado, da frequiência de amigos e parentes que visitavam o lar, das saídas femininas fez, com que recaísse sobre as mulheres exigências educacionais e comportamentais, além da rigidez dos costumes patriarcais que se pretendia manter. Além dos tradicionais vigilantes do comportamento 
feminino (família, igreja) estavam aqueles que observavam as mulheres no espaço público, ou seja, toda a sociedade tornava-se guardiã dos passos femininos, além dos olhos da lei.

A educação como contribuição na formação da mãe ideal, na verdade era usada como arma para que as mulheres soubessem como exercer com propriedade o papel de mãe, na sua contribuição com a pátria através da formação de bons cidadãos.

Esses papéis eram importantíssimos, uma vez que dupla função era responsável pela base da sociedade brasileira, a família. A estruturação do lar, criação dos filhos (futuro da nação) eram atributos femininos considerados pela maioria como missão, responsável pela implantação da fé, do amor e da religião cristã católica no seio do lar. A concepção de que a mulher tinha um importante papel a desempenhar na sociedade, por meio de sua casa, era nutrida pela idéia de sua influência com a educação de seus filhos.

Em virtude do caráter "missionário" que toda mulher virtuosa teria que desempenhar dentro do lar, esta era considerada como santa, seguindo os desígnios da Igreja e se enquadrando em um estereótipo perfeito de mulher, cultivando os atributos tidos como essencialmente femininos, pois a vida fora do lar teria o efeito de virilizar a mulher.

Ignoro o que ganhará o sexo forte em encontrar em toda parte exceto no lar, a mulher que ele desviou de seu destino. Mas ser o que perderá a mulher com esta abdicação e usurpação. À seus deveres estão ligados seus privilégios; se ela abandona uns, perderá os outros. A mulher masculina é uma espécie de fenômeno, e afasta de si toda a simpatia. (REVISTA FEMININA. O Feminismo, out. de 1916, $\mathrm{N}^{\circ} 29$, p.12)

Entretanto, a sociedade não estava repleta de "santas mulheres", era comum se ter notícias daquelas que não deviam ser imitadas, que viviam mais em contato com o meio público do que com o ambiente interno.

No geral essas mulheres eram de classes baixas e precisavam dedicar-se à subsistência, submetendo-se a trabalhos como empregadas domésticas, lavadeiras, engomadeiras, doceiras etc., visto que o grau de instrução era baixíssimo ou inexistente. A necessidade de trabalho fora do lar fazia com os quais estas mulheres não tivessem o tempo "necessário" para o cuidado do lar e dos filhos que muitas vezes as acompanhavam em suas lides, haja vista a falta de estrutura por parte do Estado que garantisse o cuidado das crianças na ausência das mães trabalhadoras, com a oferta de creches, por exemplo. Esse 
"abandono" era visto como responsável pelos lares desestruturados, bem como tendo efeito na formação dos filhos e seus aspectos higiênicos.

Nessas famílias, em que as mães precisavam trabalhar, a alimentação e moradias precárias, sem as mínimas condições de higiene, eram atribuídas à ignorância dos pobres. Os jornais por vezes registravam a situação desses lares e a responsabilidade da situação era colocada diretamente sobre a mãe.

Assim, o discurso republicano insistiu na ampliação do ensino, inclusive para mulheres pobres, e parte do objetivo educacional destinado a essas mulheres estava na preparação para se tornarem mães conscientes de suas funções.

As mães eram entendidas como multiplicadoras de conhecimento, de valores como a honra, a verdade e a religião para seus filhos e, principalmente, para suas filhas. $\mathrm{O}$ destino de lares futuros estaria nas mãos das mães que transmitiriam os conhecimentos básicos para a formação da futura mãe e esposa. Mães que ensinassem suas filhas a se afastarem do orgulho, soberba, vaidade, mentira, mundanismo, amizades erradas, conversas à toa, e qualquer outro fator que pudesse desviar a conduta moral de uma menina.

Com a preocupação de bem orientar a mulher frente ao molde burguês-cristão, foi elaborado o livro A Alma: Educação Feminina, de autoria do maranhense Coelho Neto, para direcionar a educação de meninas, destinando-se a conselhos apoiados em valores 'morais e cívicos' vigentes.

Essa obra fazia uma elaboração do perfil de mulher a ser seguido pelas meninas, instruindo acerca de vários prismas, como a questão da amizade, organização, higiene pessoal, beleza, e todo um conjunto de quesitos influenciadores no processo de formação do caráter da menina.

Segundo essa obra, a indiscrição é vista como a denúncia de "falha no caráter, que deve ser inteiriço, por que é a couraça da honra [...] A boca, uma vez aberta, é a porta por onde escapam todos os pensamentos se a Prudência não está de guarda para correr o ferrolho a tempo" (COELHO NETO, 1911, p.27).

Deste pequeno trecho do livro, pode-se extrair uma palavra-chave, a "honra". O texto denota que a mulher honrada não deve ter nenhum defeito de caráter. Sendo costume considerar a tagarelice uma característica feminina, e, portanto, um defeito, a 
mulher deveria saber a hora certa de falar, denota um conselho para as normas de civilidade e controle dos "desregramentos femininos".

$\mathrm{O}$ perfil perfeito de mulher seria aquela capaz de prevenir-se quanto ao seu futuro, "a mulher deve prevenir-se com uma reserva para o que possa acontecer de surpresa. Os dotes melhores e mais seguros são o que dão o estudo, a experiência e o conhecimento da vida" (COELHO NETO, 1911, p.79). Não era negada a importância da instrução formal, desde que ao lado desta estivesse a elaboração dos valores necessários à nova mulher, e que o estudo servisse para obtenção de seu sustento em caso de falta de um apoio masculino, ou como refinamento para ser uma boa esposa e mãe, ou seja, para exercer papel complementar junto ao homem.

A obra aborda também temáticas sobre conselhos de união familiar, amizade, ordem, a simplicidade do traje, dicas para que as meninas aprendessem os elementos serenos embasados na natureza. Destacava a missão da mulher na terra, onde cada personagem, dentro da história, tinha o espaço que lhe cabia "faça cada qual o que lhe compete e cumprirá a sua missão na terra. À mulher cabe o governo da casa e nele está compreendido o preparo da geração futura" (COELHO NETO, 1911, p.91).

A simplicidade era entendida como um atributo necessário para a menina, nada de luxo no vestir, "nos dias comuns, os vestidos devem ser como as folhas: simples, mas limpos e graciosos" (COELHO NETO, 1911, p.126). E ao lado da simplicidade, estava mais uma vez a advertência com as conversas, pois a mulher perfeita lançava-se em conversas somente com aquelas que são igualmente instruídas, tendo que livrar-se das conversas que aviltavam.

A educação era vista como porta para elaboração da nova mulher, notadamente aquela realizada nas escolas. Coelho Neto elevava o papel da professora junto à menina, explicando que a "professora fará a aluna apurar das narrativas a suma da moralidade e, leitura ou recitação, sempre atenta aos valores prosódicos e explicando o sentido das palavras, procurará influir-lhes o gosto pela boa linguagem” (COELHO NETO, 1911, p.03). A ligação do papel feminino com a pátria também era ressaltada por Coelho Neto, ao afirmar que:

E à mulher, minha filha, o ser fraco, cabe a responsabilidade maior nesse trabalho, por que, como o senhor, no dizer dos livros, criou a alma do Homem infundindo-lhe no corpo o seu 
hálito divino, a mulher mãe deve inspirar ao coração do filho o bom exemplo, que é o gérmen da perfeição. Por isto convém que a educação da mulher seja guiada com todo escrúpulo, por que o seu destino na terra é continuar a vida, perpetuando o amor. (COELHO NETO, 1911, p.140)

Esse livro era incentivador da instrução feminina, mas com a ressalva de que fosse feita com muito cuidado, para que a menina seguisse seu "passo natural" e que não se fadigasse muito na leitura. "Se fizeres os teus estudos com o devido cuidado aproveitarás o tempo sem cansar o cérebro [...] Tens ânsia de saber? Estuda. O livro deve subir ao cérebro em essência - não em palavras, mas em idéias" (COELHO NETO, 1911, p.98/99)

As virtudes femininas deveriam ser refletidas na sociedade para benefício dos homens, a obra de Gomes de Castro, intitulada As Raças Humanas - A mulher ressalta de forma bem enfática essa noção de papéis sociais rigidamente estabelecidos, como mostra o seguinte trecho.

Ora, a divindade feminina, por isso mesmo que o é, é bela, verdadeira e boa, a uma tempo: bela como a beldade; verdadeira como o axioma; e boa como a virtude. Como bela, nos seduz; como verdadeira, nos esclarece, e nos aperfeiçoa para o bem, o fito da sua bondosa natureza. (CASTRO, 1921, p.127)

Dita obra ressalta alguns dos dotes morais e físicos que deviam ser cultivados pelas mulheres com "honra e louvor", valorizando aquelas que não se importavam com a vaidade, ressaltando o poder milagroso do amor.

De forma geral, podemos notar que a sociedade se encarregava de imbuir constantemente sobre a mulher os papéis que deveria desempenhar. Isto ocorria com tal intensidade que denota uma necessidade de criação de um modelo para os padrões requisitados de "mulher perfeita". Daí a insistência em manter atualizado o discurso da submissão feminina, destacando sempre seu aspecto "naturalizado".

$\mathrm{Na}$ verdade, havia o receio de que a mulher perdesse sua "identidade materna" por meio do contato com a rua ou com os estudos mais avançados. Dentro desse contexto, houve o reforço de um modelo de mãe que estaria ligado ao exemplo cristão maior, Maria. A mãe de Deus surgiria na imagem feminina como a redentora e, fora desse padrão a mulher estaria enquadrada por meio da pecadora Eva.

A mulher não é mais identificada à serpente do Gênesis, ou a uma criatura astuta e diabólica que é preciso por na linha. Ela se transforma numa pessoa doce e sensata, de quem se espera comedimento e indulgência. Eva cede lugar docemente a Maria. A curiosa, a ambiciosa, a 
audaciosa metamorfoseia-se numa criatura modesta e ponderada, cujas ambições não ultrapassam os limites do lar. (BADINTER, 1985, p. 176)

Seguindo o exemplo de Maria, a mãe que abriu mão de sua própria vida e que se entregou totalmente ao seu sacerdócio, a mulher então deveria priorizar seu lar acima de tudo, seu recôndito e reino. Sendo assim, apesar da imagem laica da República, o papel exercido pela igreja na cristalização da imagem feminina atrelada à de Maria era fundamental, e as qualidades marianas deveriam estar presentes em todas as concepções de mulher ideal, repassadas para as mulheres por via da educação formal ou não. Deixar os prazeres e viver a resignação de uma vida devota aos seus filhos eram sinônimos de uma mãe perfeita, o tipo de cidadão que a nação esperava seria formado a partir dos ensinamentos no lar, pois na mãe estaria a responsabilidade pela formação dos cidadãos ativos.

O amor de mãe é o cofre dos mais santos afetos, o poema de cruciante dores e a grinalda de doces sorrisos! A mãe é um ente consagrado a seus filhinhos, desde o primeiro estremecimento que lhe agita o seio, até o último sopro de vida que lhe cerra os lábios. O amor de mãe vive da vida desses queridos e todo se enleva de suas graças e de seu sorrisos. - Com que ternura e meiguice olha se devota a seus filhinhos senhores de seu coração! (O TOCANTINS, 01 de ago. de 1915)

É interessante notar como o jornal apresenta um discurso repleto de adjetivos para a relação mãe e filhos, desde o sofrimento que a mãe passaria em prol dos seus, até a sensação de bem-estar proporcionada pelo privilégio de ser o "ente sagrado" de seus filhos.

A educação feminina era direcionada para o exercício de sua contribuição social de esposa e mãe, o matrimônio era entendido como o primeiro momento de realização da mulher. O processo educacional cada vez mais voltado para as mulheres gerava um certo conflito e preocupação, pois se temia que essa mulher constantemente recebendo conhecimentos científicos, em vez de envolver-se somente com aquilo que corroborasse sua missão de mãe, fosse estimulada a desenvolver outras atividades, como a profissional, o direito ao voto, ao partidarismo político, etc.

De certa forma, era temido que a mulher ao aceitar e vivenciar propostas do ambiente externo ao lar, perdesse sua essência e se desviasse de sua missão em virtude do saber e da participação política. Os resultados dessa ação poderiam ser os mais desastrosos, 
pois corria o sério risco de desvinculação da mulher com os assuntos de interesse da família, considerada base de toda a nação e tendo na mulher um importante pilar.

À mulher cabia a organização da família, e a partir do momento em que a esposa e mãe passasse a se envolver em muitas atividades fora do ambiente considerado seu por natureza, o lar, o espaço da mulher ficaria vazio e suas atribuições seriam levadas a segundo plano.

No caso do voto feminino, o forte argumento para sua negação era a divisão dos interesses dos cônjuges, levando ao desentendimento do casal, e, por conseqüência, à desestruturação do lar e da educação dos filhos. A plena cidadania com a efetiva participação política para as mulheres era entendida como uma competição aos seus afazeres, uma vez que o discurso republicano exaltava a considerada missão feminina, maximizando sua importância para o meio social.

\footnotetext{
Alguém dirá, que desse dia em diante se esfalecerá o lar que até então era o paraíso das flores; pois a mulher poderá discernir dos ideais do marido, e sairá pelas ruas pedindo votos para o seu partido e contra o partido de seu esposo.Assim o resultado será discussões diárias, e má viver entre os dois, porque não se entenderão.Não duvido que isso aconteça (REVISTA MARANHENSE, nov. de 1916).
}

A educação seria uma importante arma na formação das futuras mães, mas para tanto deveria ser bem administrada e bem direcionada. Os jornais ludovicenses contribuíram fortemente para o direcionamento daquilo que a sociedade requisitava como de uma boa mãe. Matérias nos mais diversos jornais chamam a atenção para a formação de uma mãe que se pretendia ideal, e justamente a mulher "na condição de donas de casa, jamais poderiam ultrapassar seus limites, pois caso isso acontecesse seriam virtualmente corrompidas, sendo que a estrutura familiar seria fatalmente abalada”. (MARTINS, 2004, p.12).

Com a educação e a mudança de alguns dos costumes na sociedade, a mulher estava ultrapassando os limites do lar. Ao mesmo tempo, a mulher de elite entraria mais em contato com os acontecimentos do espaço público, estaria também mais envolvida pela vigilância masculina e das instituições sociais, como igreja, a própria família, os médicos, a justiça, a escola. Todos os critérios que formulariam uma mulher para dedicar-se ao sacerdócio materno deveriam ser bem efetivados, pois "aquelas dotadas de erotismo intenso 
e forte inteligência, seriam despidas do sentimento de maternidade, característica inata da mulher normal, e consideradas extremamente perigosas"(SOIHET, 2000, p.363).

O matrimônio, como instituição, consagrava-se no interior do lar. Era nele que as relações de poder eram efetivamente estabelecidas. A própria casa possuía espaços de diferenciação, pois "na casa, coexistem lugares de representação (o salão burguês), espaços de trabalho masculinos (o escritório onde a mulher e os filhos só entram na ponta dos pés). A fronteira entre público e privado é variável, sinuosa e atravessa até mesmo o microespaço doméstico" (PERROT, 1988, p.180). Como ao homem cabia bem mais o ambiente da rua, o espaço que lhe era destinado dentro do lar era sempre relacionado a suas atividades públicas, como por exemplo, a biblioteca e o escritório.

O casamento surge então como uma relação onde a mulher tinha sua tutela transmitida do pai, irmão ou tio para o marido. O importante era manter a mulher sob jugo masculino, pois “[...] por suas agitações subras nos revela que Deus fez a mulher fraca foi confiando na generosidade do homem" (JORNAL A SINETA, 07 de set. de 1919).

A seleta alma feminina é um bonançoso céu azul, sem nuvens, um doce manancial de venturas, um lindo jardim de perfumosas flores, um plácido paraíso de magníficas delícias, um mundo de inqualificáveis maravilhas. E o gracioso corpo feminino, o adequado pedestal deste carabro peregrino. (SERRA, 1867, p.147)

O jornal $O$ Téntame apresentou um breve histórico da situação feminina frente ao matrimônio, explicando que "nos primeiros tempos" era entendida apenas como objeto de prazer e que a sua natureza se encarregou de levá-la ao lar. A partir de então o homem passou a conquistar a mulher especialmente pela força e logo se estabeleceu o casamento no regime patriarcal.

Instituída a sociedade patriarcal, a organização do casamento variou. Ao rapto sucedeu a compra, ao poder das armas a intervenção da família, mas essa intervenção nada mais era do que comercial: os pais vendiam as filhas ao mais elevado lanço, e o casamento nada mais era do que um abrigo. Escrava era a mulher comprada, pois o marido adquiria sobre ela o direito de propriedade. Se, porém o regime patriarcal elevou a mulher, abaixou-a também: estabeleceu a união, mas privou à mulher todo direito toda liberdade. (JORNAL O TENTAME, 07 de dez. de 1919).

No livro Alma do Sertão: Desafios a mulher julgada pelos homens, de Catullo da Paixão Cearense é apresentada uma série de opiniões masculinas sobre a mulher e sobre como alguns homens gostariam que as mulheres se comportassem. Algumas concepções 
perpassam a idéia cristalizada de inferioridade e dependência, de ridicularização da mulher e sua incapacidade de direcionar sua vida, ou enfatizando o endeusamento por meio de elementos como honra e castidade etc.

\begin{abstract}
A mulher é um planeta. Não tem luz própria. Vista de longe, com o telescópio da ilusão, é como a lua. Encanta! Mas, de perto, é um astro morto, sem vida. Ainda assim, ela é e será o sol do nosso sistema planetário. Quando não exerce a sua atração sobre o homem, ele, fatalmente, dispersa-se nas profundezas do Nada. (CEARENSE, 1928, p.126)
\end{abstract}

Usando a metáfora do sistema solar, apresenta a idéia de incapacidade feminina, sendo a mulher um planeta cujo objetivo seria exercer atração sobre o homem. No entanto, a comparação com um astro sem luz própria, um "astro morto" tentava mostrar a incapacidade feminina de auto-gestão ao mesmo tempo em que sua comparação com o sol servia para mostrar sua vitalidade em benefício do homem.

\footnotetext{
Vejo que a mulher de hoje não vale a mulher do passado. A de hoje só quer ser doutora, professora, funcionária pública, aviadora, eleitora, senadora, deputada [...] o diabo a quatro, enquanto a outra era a doutora da casa, a funcionária da cozinha e a deputada do seu marido. Que saudade do passado, meus caros amigos! A mulher há de tornar a ser mulher, no dia em que deixar o atropelo da moda, a vaidade de ser doutora, e voltar pois, assim como vai, há de chegar um tempo em que ela não será mais nem homem nem mulher! Meus senhores: quereis a opinião de um rude sobre as mulheres? Panelas e mais panelas é o de que elas precisam. (CEARENSE, 1928, p.144/145).
}

Neste trecho fica evidente a preocupação do autor com a frequiência da mulher no ambiente público, daquela que estava cada vez mais preocupada com sua profissão e que de certa forma já não se dedicava mais completamente ao lar, e nem se limitava a seus muros, estudava mais e tornava-se mais exigente na defesa do que considerava seus direitos. Essa relativa emancipação feminina assustava os homens e os fazia sentir saudade do momento em que as mulheres dedicavam-se exclusivamente aos filhos e ao lar, em que a reclusão no ambiente doméstico era como uma garantia de sua fidelidade e dedicação exclusivas a seus filhos e marido.

À mulher cabia a organização da família. A partir do momento em que a esposa e mãe passasse a se envolver em muitas atividades fora do ambiente considerado seu por natureza, o lar, o espaço da mulher, ficaria vazio e suas atribuições seriam levadas a segundo plano.A educação feminina era direcionada para o exercício de sua contribuição social de esposa e mãe, o matrimônio era entendido como o primeiro momento de 
realização da mulher. Então, pode-se perceber que a educação formal feminina era disseminadora de transmissão de valores que reforçavam a divisão sexuada dos papéis sociais.

A educação destinada às mulheres no início do século XX estava marcada por um paradoxo: considerava-se que a mulher necessitava ampliar sua educação para cumprir melhor seus papéis de esposa e mãe; por outro lado, desaprovava-se uma educação emancipadora que conduzisse a mulher a sua plena autonomia, tornando-se uma concorrente do homem.

Em São Luís, na égide dos governos republicanos, verificou-se uma ampliação da educação feminina escolarizada, com a criação da Escola Normal, preparando as moças para o magistério primário, bem como as primeiras mulheres cursando o nível superior.

As mudanças que ocorriam na cidade sob o signo da modernidade, com mais espaços se abrindo para mulheres das camadas médias e altas, circulando sozinhas nas praças e avenidas, freqüentando o cinema, teatro, lojas de luxo, geravam preocupações com a imagem feminina que conseqüentemente atingiriam a ordem familiar. Neste momento, houve um recrudescimento do discurso dos papéis femininos pautados no tripé filha, esposa e mãe. Seja com o aval científico ou religioso, o discurso sobre a educação feminina era acompanhado pela idealização da mulher como a missionária da implantação do amor a Deus e à Pátria, da responsável pela harmonia da família e pela educação dos filhos.

A identidade materna continuava sendo a grande representação feminina, responsável pelo reforço da diferenciação entre os dois sexos: aos homens caberiam os direitos de plena cidadania, com superioridade jurídica, uma vez que eram vistos como os chefes da família e do Estado; e às mulheres era oferecido o trono doméstico, como rainha do lar, em que sua submissão era "recompensada" pelo discurso da exaltação da mulher mãe e pelos pretensos privilégios da dona de casa.

\section{REFERÊNCIAS}

ABRANTES, Elisabeth. A Educação do "Bello Sexo" em São Luís na segunda metade do século XIX.UFPE: Recife, 2002. Dissertação de mestrado. 
ANDRADE, Beatriz Martins. O discurso Educacional do Maranhão na Primeira República. São Luís: EDUFMA, 1984.

ARAÚJO, Rosa Maria Barboza de. A vocação do prazer: a cidade e a família no Rio de Janeiro republicano. Rio de Janeiro: ROCCO, 1993.

BANDINTER, Elisabeth. Um amor conquistado: o mito do amor materno. Rio de Janeiro: Nova Fronteira, 1985, $6^{\circ}$ edição.

BOURDIER, Pierre. A dominação masculina. Rio de Janeiro: Bertrand Brasil, 2005, $4^{\circ}$ edição.

BULCÃO, Raquel Paixão. De "Curso espera marido" a “Orgulho da nossa gente”. São Luís: UFMA, 2002. Monografia.

CEARENSE, Catullo Paixão. Alma do Sertão. Typografia Maranhense, 1928. Acervo de Obras Raras da Biblioteca Publica Benedito Leite.

CASTRO, Gomes de. As raças humanas: A mulher. Rio de Janeiro, 1921.

COELHO NETO. A Alma: Educação Feminina. Rio de Janeiro: Ed. J. Ribeiro dos Santos, 1911. Acervo de Obras Raras da Biblioteca Benedito Leite, São Luís.

CORREIA, Maria da Glória Guimarães. Nos fios da trama: Quem é essa mulher? Cotidiano e trabalho do operariado feminino em São Luís na virada do século XIX. São Luís: EDUFMA, 2006.

COSTA, Jurandir Freire. Ordem médica e norma familiar. São Paulo: Graaal, 1979.

D`INCAO, Maria Ângela. Mulher e família burguesa. In: NOVAIS. Fernando. História da vida privada no Brasil. vol.2. Companhia das letras, 2006.

JORNAL A REAÇÃO, 1913. Acervo de Periódicos da Biblioteca Pública Benedito Leite.

LEANDRO, Eulálio. A mulher na visão humanística de Coelho Neto. Imperatriz: Ética, 2004.

MALUFF, Marina e MOTT, Maria Lúcia. Recônditos do mundo feminino. In: NOVAIS, Fernando. História da vida privada no Brasil, vol.3. São Paulo: Companhia das Letras, 2006.

MARTINS, Ana Gardênia Lima. "A dona de casa" - Conselhos e receitas para a rainha do lar (1894). São Luís: UFMA, 2004. Monografia.

NAZZARI, Muriel. O Desaparecimento do dote: mulheres, famílias e mudança social em São Paulo-1600/1900. São Paulo: Companhia das Letras, 2001. 
PERROT, Michele. Os excluídos da história: operários, mulheres e prisioneiros. Rio de Janeiro: Paz e Terra, 1988.

REVISTA DO NORTE, 01 de setembro de 1901, $\mathrm{n}^{\circ}$ 1, ano I (Artigo - "O colégio do Pires").

REVISTA FEMININA, outubro de 1916. Biblioteca Pública Nacional. Rio de Janeiro.

REVISTA MARANHENSE, novembro de 1916. Acervo de periódicos da Biblioteca Pública Benedito Leite.

REVISTA ELEGANTE, 30 de junho de 1893. Acervo de Periódicos da Biblioteca Pública Benedito Leite.

SALDANHA, Lílian Maria Leda. A instrução pública maranhense na primeira década republicana (1889-1899). São Luís: UFMA, 1992. Dissertação de mestrado.

SERRA, Joaquim. Um coração de mulher - Poema - Romance. São Luis: Typ. B. de Mattos. 1867. Acervo de Obras raras da Biblioteca Pública Benedito Leite.

SOIHET, Rachel. Mulheres pobres e violência no Brasil urbano. In: PRIORE, Mary Del. História das Mulheres no Brasil. São Paulo: Ed. Contexto, 2000. 